Dr Radomir Janković, pukovnik, dipl. inž. Vojnotehnički institut,

\section{RAČUNARSKA SIMULACIJA UTROŠKA MUNICIJE DO PRVOG POGOTKA U IZNENADNOM SUKOBU DVA TENKA}

UDC: $[623.451: 623.438]: 355.424 .5$

Rezime:

Predmet ovog rada je računarska simulacija utroška municije do prvog pogotka glavnih oruđa dva tenka u iznenadnom sukobu. Prvi pogodak je bitan, jer često ima presudan uticaj na krajnji ishod sukoba tenkova. Tenkovi su naoružani različitim glavnim oruđima, od kojih je jedno protivoklopna vođena raketa, a drugo top sa brzim potkalibarnim probojnim projektilima. Definisan je iznenadni sukob tenkova, date su polazne pretpostavke i prikazan je simulacioni model pomoću grafičke predstave kretanja platformi, matematičkih transformacija $i$ algoritamskog opisa. Model je implementiran pomoću simulacionog jezika GPSS World. Analizirani su rezultati 10 eksperimenata, pri različitim vrednostima početnog rastojanja tenkova u iznenadnom sukobu.

Ključne reči: simulacija, tenk, sukob, glavno oruđe, utrošak municije.

\title{
COMPUTER SIMULATION OF AMMUNITION CONSUMPTION UNTIL THE FIRST HIT IN A SUDDEN TWO-TANK CONFLICT
}

Summary:

The subject of the paper is computer simulation of ammunition consumption until the first hit in a sudden two-tank conflict. The first hit is important because it is often decisive in a two-tank conflict issue. The tanks are armed with different main weapons, one of which is a guided antiarmour missile, and the other is a classic gun which fires armour piercing rounds. The sudden conflict of tanks has been defined, starting assumptions have been given and the simulation model has been presented by means of the graphic representation of the platforms moving, mathematical transforms and algorithmic description. The model has been implemented by means of the GPSS World simulation language. The results of 10 experiments have been analysed, with various intial distances of the tanks in conflict.

Key words: simulation, tank, conflict, main weapon, ammunition consumption.

\section{Uvod}

U ovom radu predstavljeni su neki od rezultata sopstvenog istraživanja $u$ oblasti složenih vojnih sistema. Predmet rada je simulacija utroška municije glavnih oruđa do prvog pogotka u neočekivanom sukobu dva tenka.

U savremenim operacijama čiji je nosilac, ili u kojima učestvuje kopnena vojska (KoV), oklopne i mehanizovane jedinice (OiMJ) imaju jednu od odlučujućih uloga. Mada po živoj sili malobrojne, one predstavljaju oko jedne trećine vatrene moći i oko 20 procenata vrednosti opreme kopnene vojske. To je razlog što se pri konstruisanju novih, ili (sve aktuelnije) modernizaciji postojećih tenkova, pažljivo razmatraju svi njihovi pojedinačni podsistemi, kao i ukupan učinak 
tih podsistema u okviru tenka kao složenog vojnog sistema - naoružane mobilne platforme (NMP).

Jedan od najznačajnijih podsistema tenka kao NMP je njegovo glavno oruđe. $\mathrm{U}$ najnovijoj generaciji tenkova postoje dva suprotstavljena pristupa $\mathrm{u}$ izboru glavnog oruđa. To su protivoklopna raketa, vođena po laserskom snopu, koja se lansira iz cevi topa, i klasičan top koji ispaljuje brze potkalibarne probojne projektile. Imajući u vidu cenu tih oruđa, sistema za upravljanje njihovom vatrom i ostalih podsistema tenkova koji utiču na njihovo uspešno dejstvo, pristupilo se istraživanjima u kojima se, primenom metode računarske simulacije, ispituje uticaj glavnog oruđa na ishod iznenadnog sukoba dva tenka, kao jednog od najzahtevnijih oblika izvođenja borbenih dejstava tenka kao naoružane mobilne platforme.

U radu [1] uveden je simulacioni model sukoba dve naoružane mobilne platforme. Cilj izrade takvog simulacionog modela je da se, putem eksperimenata sa razvijenim simulatorom, istraži uticaj različitih parametara NMP kao sistema na tok i ishod sukoba, $i$ da se donesu odluke o tehničkim rešenjima i načelima borbene upotrebe NMP. U radu [2] uvedeni su osnovni mehanizmi za simulaciju sukoba dve NMP:

$-\tau(\mathrm{d})$ : transformacija datog rastojanja u vreme;

$-\lambda(\mathrm{t})$ : transformacija datog vremena $\mathrm{u}$ rastojanje;

- VD: vatreno dejstvo po protivničkoj NMP;

$-p_{p}$ : funkcija verovatnoće pogotka protivničke NMP;

$-p_{u}$ : funkcija verovatnoće uništenja pogođene NMP;
- REM: reakciona matrica;

- KTP: komunikacija transakcija sa preusmeravanjem.

Ti mehanizmi poslužili su za razvoj simulatora sukoba tenkova T-1 i T-2, radi ispitivanja uticaja izbora glavnog oruđa na ishod sukoba [3, 4]. U radu [5] razvijen je model i izvršena simulacija dva tenka, koji imaju identične karakteristike, izuzev glavnog oruđa (tabela). Kod jednog od njih to je klasičan top koji ispaljuje protivoklopne probojne potkalibarne projektile, a kod drugog protivoklopna vođena raketa. Tenkovi u sukobu kreću se jedan drugom u susret.

Uporedne karakteristike tenkova u sukobu

\begin{tabular}{|l|l|l|}
\hline \multicolumn{1}{|c|}{ Naziv } & \multicolumn{1}{c|}{ T-1 } & \multicolumn{1}{c|}{ T-2 } \\
\hline Maksimalna brzina $V_{i}(\mathrm{~m} / \mathrm{s})$ & 18 & 18 \\
\hline Azimut kretanja $\alpha_{i}\left({ }^{\circ}\right)$ & $\alpha_{1}$ & $\alpha_{1}+180$ \\
\hline Domet ON-sprava $D_{O N-i}(\mathrm{~m})$ & 5000 & 5000 \\
\hline Domet oruđa $D_{O R-i}(\mathrm{~m})$ & 5000 & 2000 \\
\hline Verovatnoća pogađanja $p_{O R-i}(\%)$ & $(\mathrm{sl} .4)$ & $(\mathrm{s} l .4)$ \\
\hline Vreme pripreme oruđa $T_{O R-i}(\mathrm{~s})$ & $10 \pm 4$ & $8 \pm 2$ \\
\hline Brzina leta projektila $V_{L-i}(\mathrm{~m} / \mathrm{s})$ & 300 & 1800 \\
\hline Veličina borbenog kompleta $B K_{i}$ & 4 & 45 \\
\hline
\end{tabular}

Na slici 1 prikazane su verovatnoće prvih pogodaka tenkova T-1 i T-2 u funkciji njihovog početnog rastojanja $u$ iznenadnom sukobu. Uočavaju se tri zone: do 2000 m, gde u većem broju slučajeva prvi pogađa tenk T-2, od 2000 do $2500 \mathrm{~m}$ (osenčeno) gde dolazi do promene i od 2500 do $5000 \mathrm{~m}$, gde sa povećanjem početnog rastojanja sve više dominira tenk T-1. Rezultati simulacionih eksperimenata ukazuju na to da na rastojanjima do $2000 \mathrm{~m}$ prednost $\mathrm{u}$ iznenadnom sukobu ima tenk T-2, naoružan klasičnim topom koji ispaljuje brze potkalibarne probojne projektile, a na rastojanji- 


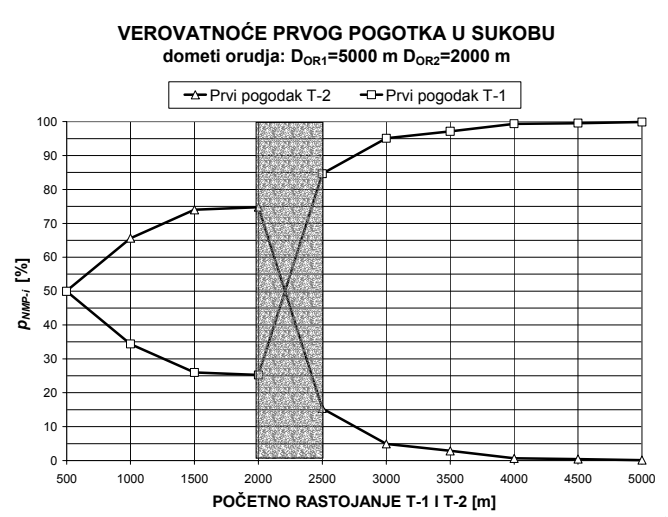

Sl. 1 - Verovatnoće prvog pogotka tenkova u iznenadnom sukobu

ma od $2500 \mathrm{~m}$ do $5000 \mathrm{~m}$ tenk T-1, naoružan protivoklopnim vođenim raketama.

$\mathrm{U}$ ovom radu najpre je definisan tenk kao naoružana mobilna platforma, a zatim je dat osvrt na razvijeni simulacioni model. $U$ analizi rezultata 10 eksperimenata izvršenih sa programom simulatorom implementiranim pomoću jezika
GPSS World, razmatraju se utrošci municije $\mathrm{UM}_{1}$ i $\mathrm{UM}_{2}$ glavnih oruđa tenkova $\mathrm{T}-1$ i T-2, respektivno.

\section{Tenk: naoružana mobilna platforma}

Cilj simulacije je istraživanje iznenadnog sukoba tenkova $[2,3,4,5]$, vanrednog događaja do kojeg dolazi kada se sretnu dva protivnička tenka, koji se nalaze $u$ sopstvenim nezavisnim misijama, i do tog susreta ne znaju jedan za drugog. Tenk je ofanzivno oklopno borbeno vozilo, što znači da mu je stepen zaštite najveći na prednjoj strani, nešto manji na bočnim stranama, a najmanji na zadnjoj. Izgled i osnovne dimenzije tipičnog savremenog tenka prikazani su na slici 2 . Imajući u vidu te dimenzije, raspored područja posebno važnih za funkcionisanje tenka i njihovu osetljivost na pogotke, takav tenk se u ovoj simulaciji aprok-

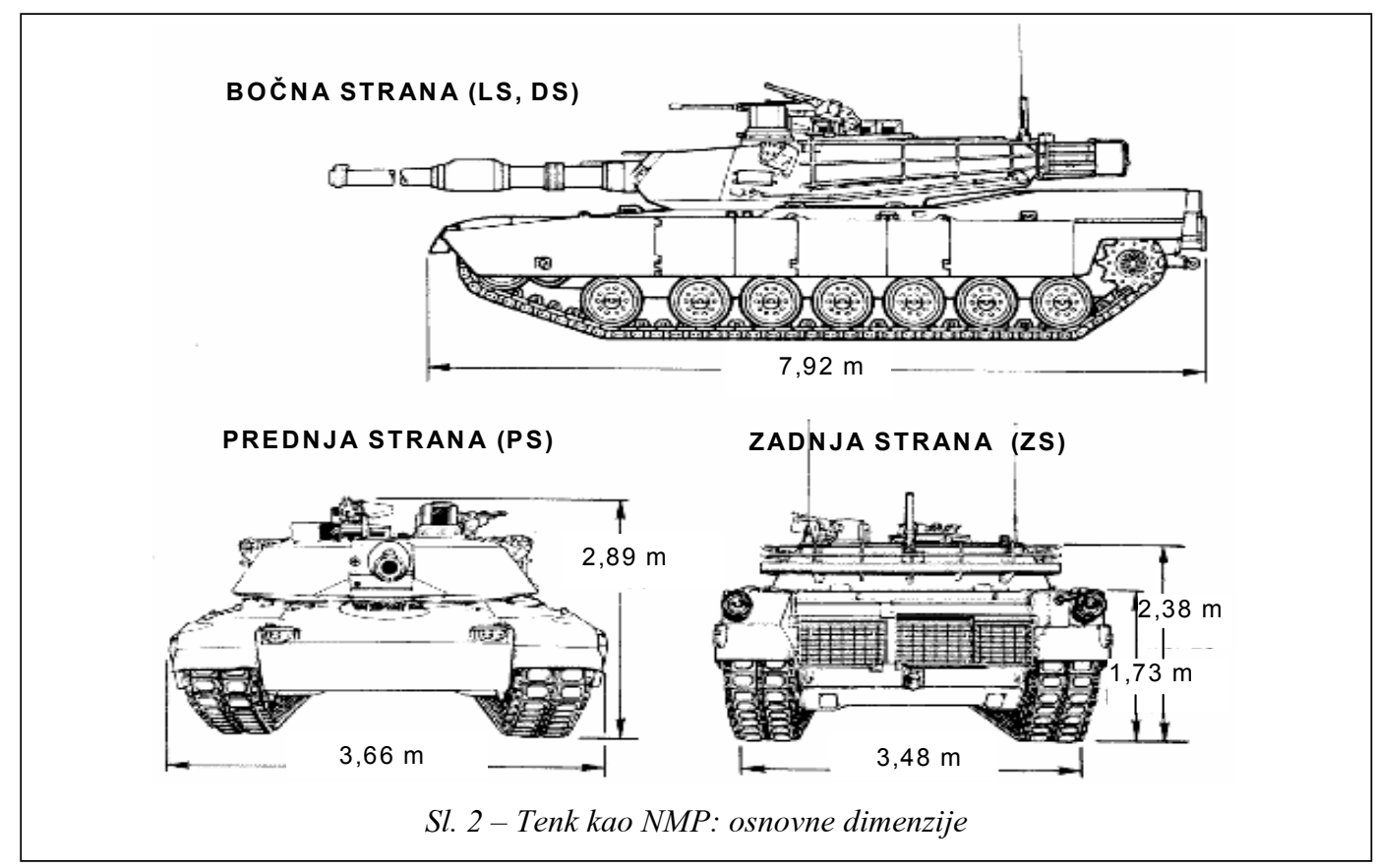


simira paralelopipedom, čije su dimenzije: širina $a=3,5 \mathrm{~m}$, dužina $b=8 \mathrm{~m}$ i visina $c=3 \mathrm{~m}$.

Osnovni pogon (motor, transmisija) nalazi se u zadnjem delu tenka [5] i najizloženiji je sa zadnje, manje sa bočnih, a najmanje sa prednje strane tenka. Hodni mehanizam (gusenice, pogonski točkovi, itd.) najmanje je izložen sa prednje, više sa zadnje, a najviše sa bočnih strana tenka. Mehanizam za pokretanje kupole najviše je izložen u delu na sastavu između kupole i tela tenka.

Osmatračko-nišanske (O-N) sprave komandira i nišandžije zamenljive su u okviru svojih osnovnih funkcija. Pored toga, svaka od njih u izvesnoj meri može da zameni uništenu osmatračku spravu vozača.

\section{Iznenadni sukob tenkova}

Pojedine faze iznenadnog sukoba dva tenka $[1,3,4]$ prikazane su na slici 3. Tenkovi u sukobu, T-1 i T-2, predstavljeni su simbolički tačkama - svojim položajima u prostoru u kojem se kreću, zonama detekcije pomoću njihovih senzora za osmatranje i upravljanje vatrom (širi krugovi), i zonama mogućeg vatrenog dejstva oruđa (zasenčeni krugovi).

Deo slike 3(a) prikazuje pretkonfliktnu fazu u kojoj još nema sukoba, a tenkovi T-1 i T-2 ne znaju za postojanje protivnika, jer se oba nalaze van dometa senzora S-1 i S-2 za osmatranje i upravljanje vatrom, odnosno van njihovih zona detekcije.

Sukob nastaje u fazi koja je prikazana u delu (b) slike 3, kada je bar jedan od tenkova T-1 i T-2 ušao u zonu detekcije senzora protivnika. Tada tenk, čija je osmatračko-nišanska sprava detektovala protivnika, uzima elemente za upravljanje vatrom i priprema glavno oruđe za dejstvo.

Vatreno dejstvo glavnog oruđa počinje u fazi prikazanoj u delu (c) na slici 3 . Uslov je da bar jedan od tenkova uđe u zonu vatrenog dejstva oruđa protivnika, a da je on, sa svoje strane, uzeo elemente za upravljanje vatrom i ima raspoloživo i

(d)

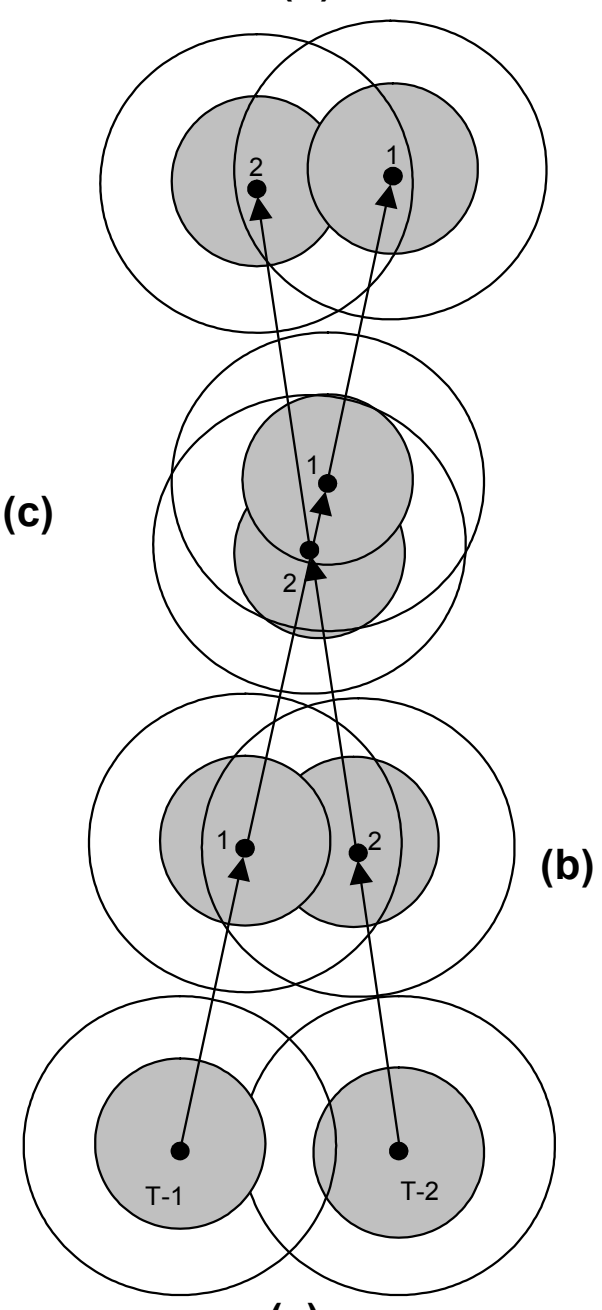

(a)

Sl. 3 - Faze sukoba tenkova T-1 i T-2 
pripremljeno oruđe. U ovoj fazi, koja predstavlja suštinu iznenadnog sukoba, dolazi do međusobne razmene vatrenog dejstva glavnih oruđa tenkova T-1 i T-2, koji tako pokušavaju da unište jedan drugog. Svaki od njih nastavlja to da radi sve dok ne nastupi jedan od sledećih događaja:

- protivnički NMP je pogođen dejstvom sopstvenog oruđa;

- dalje vatreno dejstvo je onemogućeno, usled otkaza oruđa, nestanka municije ili neke nove odluke;

- usled daljeg kretanja međusobno rastojanje tenkova T-1 i T-2 postalo je veće od dometa njihovih glavnih oruđa.

Ukoliko je jedan od tenkova pogođen vatrenim dejstvom oruđa drugog ten$\mathrm{ka}$, tada se sukob završava njegovim porazom. Ukoliko dođe do otkaza oruđa ili potpunog utroška municije, tenk i dalje učestvuje u sukobu, ali bez mogućnosti aktivnog dejstva i sa znatno smanjenim izgledima za preživljavanje.

Ukoliko, daljim kretanjima, tenkovi izađu iz zona vatrenog dejstva oruđa, sukob prelazi u sledeću fazu, prikazanu na delu slike 3 (d). To je poslednja, postkonfliktna faza sukoba, kada je obustavljeno vatreno dejstvo, ali se tenkovi još uvek nalaze u zoni detekcije senzora. Oni se međusobno osmatraju sve do izlaska iz zona osmatranja, čime se, u ovom slučaju, sukob završava opstankom oba tenka.

\section{Simulacioni model}

Polazne pretpostavke za izradu simulacionog modela neočekivanog sukoba su:

- tenkovi T-1 i T-2 kreću se jedan drugom $\mathrm{u}$ susret, pod azimutima $\alpha 1 \mathrm{i}$ $\alpha 2=\alpha 1+180^{\circ}$, svojim maksimalnim brzinama V1 i V2. Do sukoba ne znaju jedan za drugog;

- T-1 ima osmatračko-nišansku spravu S-1, a T-2 spravu S-2, koje služe za osmatranje i upravljanje vatrom. Sprave su definisane svojim krajnjim dometima $D_{S-1}$ i $D_{S-2}$;

- tenkovi imaju oruđa OR-1 i OR-2 koja mogu da pogode protivnika sa verovatnoćama $p_{O R-1}$ i $p_{O R-2}$. Prosečna vremena pripreme oruđa za dejstvo su $T_{O R-1} \mathrm{i}$ $T_{O R-2}$, dometi $D_{O R-1}$ i $D_{O R-2}$, brzine leta projektila do cilja $V_{L-1}$ i $V_{L-2}$ i veličine borbenih kompleta municije $B K_{1}$ i $B K_{2}$;

- sukob tenkova T-1 i T-2 počinje kada bar jedan od njih otkrije protivnika pomoću svoje osmatračko-nišanske sprave. Kada sukob jednom počne, više nema odustajanja do njegovog okončanja;

- sukob prestaje kada jedan tenk prvi put pogodi protivnika ili kada usled potpunog utroška borbenih kompleta oruđa OR-1 i OR-2 ostanu bez municije.

Simulacioni model sukoba dve naoružane mobilne platforme razvijen je $\mathrm{i}$ opisan u $[1,3,4]$. Tenkovi u sukobu kreću se jedan drugom u susret, svojim maksimalnim brzinama $V_{1}$ i $V_{2}$. Na slici 4 data je grafička predstava modela kretanja tenkova T-1 i T-2 u dvodimenzionalnom prostoru.

Simulacioni model sukoba T-1 i T-2 je diskretan i dinamički, orijentisan na događaje. Realizovan je pomoću simulacionog jezika GPSS World [6]. Tenkovi T-1 i T-2 predstavljaju se GPSS transakcijama [6], koje u svojim parametrima nose sve relevantne informacije (koordinate trenutnog položaja, brzine i sl.). Aktivnosti sistema u modelu predstavljaju se čistim vremenskim kašnjenjima. 


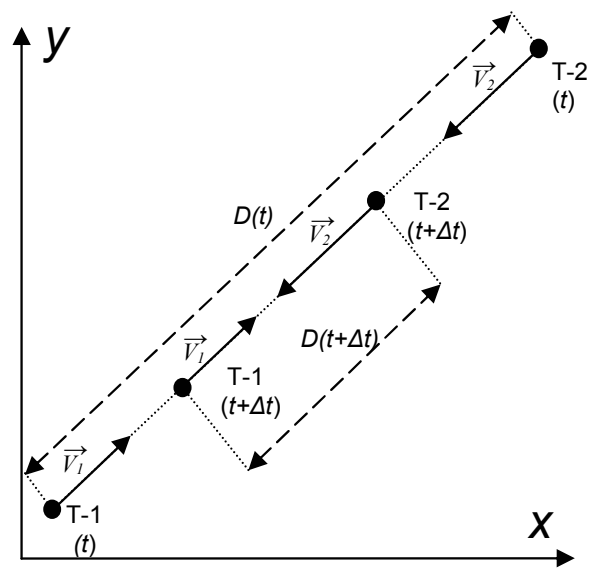

Sl. 4 - Kretanje tenkova u sukobu

Nastajanje glavnih događaja u sistemu zavisi od međusobnog rastojanja $D$ platformi. Rastojanje određuju trenutne koordinate T-1 i T-2. U modelu je zato potrebna transformacija datog rastojanja $D$ u odgovarajuci interval $\Delta t$ koji protekne dok se ne postigne zadata veličina rastojanja $D$, odnosno dok se ne stekne uslov za nastanak odgovarajućeg događaja u simuliranom sistemu.

Interval $\Delta t$, u slučaju modela sa slike 4, predstavlja realno pozitivno rešenje kvadratne jednačine:

$$
A \cdot(\Delta t)^{2}+B \cdot \Delta t+C-D=0
$$

odnosno

$$
\Delta t_{1,2}=\frac{-B \pm \sqrt{B^{2}-4 A(C-D)}}{2 A}
$$

gde su:

$$
\begin{aligned}
& A=V_{2}^{2}+V_{1}^{2}-2 V_{2} V_{1} \cos \left(\alpha_{2}-\alpha_{1}\right) \\
& B=2\left\{\left[x_{2}(t)-x_{1}(t)\right]+\left(V_{2} \sin \alpha_{2}-V_{1} \sin \alpha_{1}\right)+\right. \\
& \left.+\left[y_{2}(t)-y_{1}(t)\right]\left(V_{2} \cos \alpha_{2}-V_{1} \cos \alpha_{1}\right)\right\}
\end{aligned}
$$

$$
C=\left[x_{2}(t)-x_{1}(t)\right]^{2}+\left[y_{2}(t)-y_{1}(t)\right]^{2}
$$

Ako postoje dva realna pozitivna rešenja, u modelu se bira manje od njih - interval $\Delta t$ za koji će rastojanje između platformi prvi put dostići zadatu vrednost. Ako nema realnog rešenja, razmatrani događaj, pod datim uslovima, nikada neće nastupiti. Trajanje neke aktivnosti $\mathrm{u}$ sistemu, $\mathrm{u}$ intervalu $\Delta t$, imaće za posledicu po svom okončanju, pored ostalog, i promenjeno rastojanje platformi $D(t+\Delta t)$. Da bi se odredilo to novo rastojanje, potrebno je izvršiti transformaciju datog vremena $\mathrm{u}$ rastojanje. U slučaju modela sa slike 4, novo međusobno rastojanje platformi $D(t+\Delta t)$ u zavisnosti od proteklog intervala $(\Delta t)$ dato je izrazom:

$$
D(t+\Delta t)=\sqrt{A \cdot(\Delta t)^{2}+B \cdot \Delta t+C}
$$

gde su veličine A, B i C takođe određene izrazima (3), (4) i (5), respektivno.

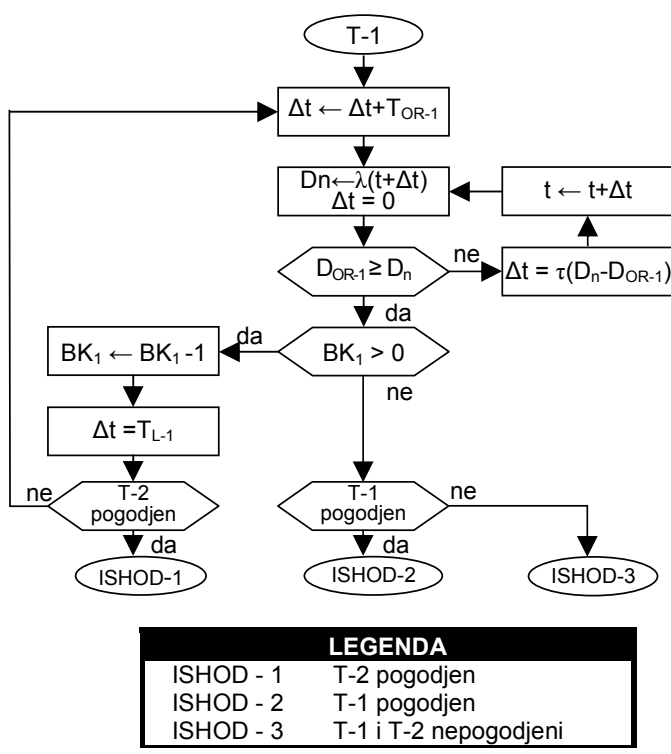

Sl. 5 - Modul za simulaciju aktivnosti tenka T-1 
Simulator sukoba T-1 i T-2 sastoji se od četiri modula [1]. Na slici 5 prikazan je algoritamski opis modula za simulaciju aktivnosti tenka T-1 u sukobu sa T-2.

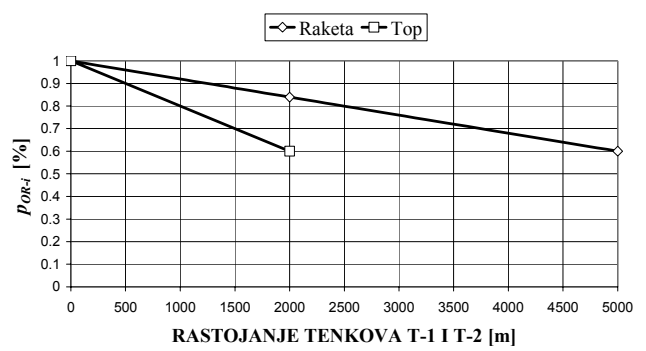

Sl. 6 -Verovatnoće pogađanja oruđa OR-1 i OR-2

Na slici 6 date su raspodele verovatnoća pogađanja protivničkog tenka glavnim oruđima OR-1 i OR-2 u njegovu izloženu (prednju) stranu, u funkciji od međusobnog rastojanja tenkova $\mathrm{T}-1$ i T2 . Vidi se da protivoklopna vođena raketa ima veću verovatnoću pogađanja, i da je efikasna do $5000 \mathrm{~m}$, za razliku od potkalibarnog probojnog projektila koji ima efikasan domet do $2000 \mathrm{~m}$.

\section{Analiza rezultata eksperimenata}

Pomoću realizovanog programa-simulatora izvršeno je 10 eksperimenata $u$ kojima je simulirano ukupno 100000 iznenadnih sukoba tenkova T-1 i T-2. U simuliranim sukobima tenkovi su se kretali jedan drugom u susret, izlažući dejstvu glavnog oruđa protivnika svoje čeone površine, koje su najmanje i najbolje zaštićene.

U radu [4, 5] analiziran je učinak dejstva glavnog oruđa po protivničkom tenku, u zavisnosti od početnog rastojanja u sukobu i veličine borbenog kompleta $\mathrm{BK}_{1}$ (broja raketa kojim raspolaže posada tenka T-1). Jedan od zaključaka bio je da postoje tri zone (slika 1): do $2000 \mathrm{~m}$, gde u većem broju slučajeva prvi pogađa tenk T-2, od 2000 do $2500 \mathrm{~m}$, gde dolazi do promene i od 2500 do $5000 \mathrm{~m}$, gde sa povećanjem početnog rastojanja sve više dominira tenk $\mathrm{T}-1$. Rezultati simulacionih eksperimenata ukazali su na to da na rastojanjima do 2000 $\mathrm{m}$ prednost $\mathrm{u}$ iznenadnom sukobu ima tenk T-2 naoružan klasičnim topom koji ispaljuje brze potkalibarne probojne projektile, a na rastojanjima od $2500 \mathrm{~m}$ do $5000 \mathrm{~m}$ tenk T-1, naoružan vođenim protivoklopnim raketama.

U ovom radu analiziraju se utrošci municije u sukobu tenkova iz borbenih kompleta glavnih oruđa OR-1 ( $\mathrm{UM}_{1}$, broj utrošenih protivoklopnih vođenih raketa) i OR-2 ( $\mathrm{UM}_{2}$, broj utrošenih potkalibarnih probojnih projektila). Rezultati eksperimenata prikazani su na slikama $7,8 \mathrm{i}$ 9, gde se razmatraju:

- srednje vrednosti utrošaka municije $\mathrm{UM}_{1} \mathrm{i} \mathrm{UM}_{2} \mathrm{u}$ zavisnosti od početnog rastojanja $\left(\mathrm{D}_{0}\right)$ tenkova u sukobu T-1 i T-2;

- kumulativne raspodele utroška $\mathrm{UM}_{1}$, za vrednosti $\mathrm{D}_{0} \in\{500,2000$, 2500, 5000\} metara;

- kumulativne raspodele utroška $\mathrm{UM}_{2}$, za vrednosti $\mathrm{D}_{0} \in\{500,2000$, 2500, 5000\} metara.

Na slici 7 prikazane su srednje vrednosti utrošaka municije $\mathrm{UM}_{1}$ i $\mathrm{UM}_{2}$, u zavisnosti od početnog rastojanja tenkova T-1 i T-2 u iznenadnom sukobu i veličine borbenog kompleta $\mathrm{BK}_{1}$ koja u ovom razmatranju ima vrednost četiri protivoklopne vođene rakete. Srednja vrednost utroška protivoklopnih vođenih raketa $\left(\mathrm{UM}_{1}\right)$ stalno raste sa povećanjem početnog rastojanja tenkova $\mathrm{D}_{0}$. U zoni početnih rastojanja $\mathrm{D}_{0}$ od $500 \mathrm{~m}$ do $2000 \mathrm{~m}$, srednja vrednost $\mathrm{UM}_{1}$ sporo linearno raste od 0,701 do 0,805 raketa po su- 
SREDNJE VREDNOSTI UTROŠAKA MUNICIJE UM ${ }_{1}$ I UM U ZAVISNOSTI OD POČETNOG RASTOJANJA T-1 I T-2

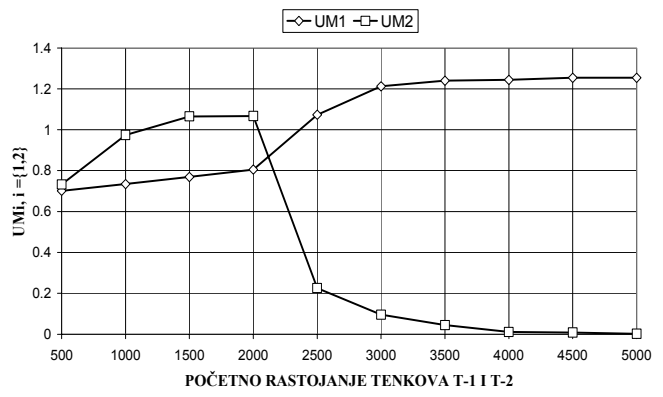

Sl. 7 - Srednje vrednosti utrošaka municije u zavisnosti od početnog rastojanja tenkova

kobu. U zoni promene, za $\mathrm{D}_{0}$ od $2000 \mathrm{~m}$ do $2500 \mathrm{~m}$, srednja vrednost $\mathrm{UM}_{1}$ brže poraste do 1,073 , a na većim početnim rastojanjima, do krajnjeg dometa raketa od $5000 \mathrm{~m}, \mathrm{UM}_{1}$ postepeno prelazi u zasićenje koje iznosi u proseku 1,254 rakete u sukobu.

Sa druge strane, srednja vrednost utroška potkalibarnih probojnih projektila $\left(\mathrm{UM}_{2}\right)$, za $\mathrm{D}_{0}$ od $500 \mathrm{~m}$ do $1500 \mathrm{~m}$, najpre nelinearno raste od 0,732 do svog maksimuma od 1,067 potkalibarnih projektila po sukobu, koji zadržava i dalje do $\mathrm{D}_{0}=2000 \mathrm{~m}$, što je i granica efikasnog dometa oruđa OR-2. U zoni promene, do $2500 \mathrm{~m}, \mathrm{UM}_{2}$ naglo opada na

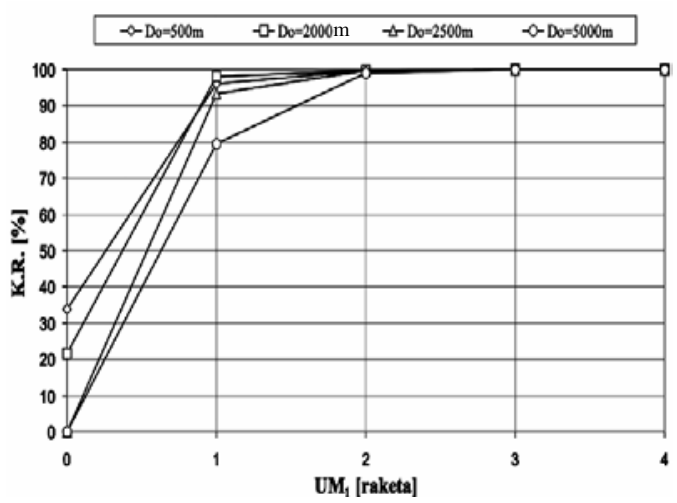

Sl. 8 - Kumulativne raspodele utroška raketa u zavisnosti od početnog rastojanja tenkova
0,225 projektila po sukobu. Sa daljim povećavanjem početnog rastojanja do $\mathrm{D}_{0}=4000 \mathrm{~m}, \mathrm{UM}_{2}$ opada do 0 (tenk T-2 nije uspeo da ispali ni jedan potkalibarni projektil u sukobu), koju vrednost zadržava i na svim većim razmatranim početnim rastojanjima do $\mathrm{D}_{0}=5000 \mathrm{~m}$ (granica efikasnog dometa oruđa OR-1).

Na slici 8 prikazane su kumulativne raspodele utroška municije $\mathrm{UM}_{1}$, za vrednost borbenog kompleta $\mathrm{BK}_{1}=4$ rakete, u zavisnosti početnog rastojanja tenkova T-1 i T-2 u iznenadnom sukobu. $\mathrm{Na}$ početnom rastojanju $\mathrm{D}_{0}=500 \mathrm{~m} \mathrm{u}$ $33,97 \%$ sukoba, tenk T-1 ne uspeva da lansira raketu koja će uspešno da doleti do T-2. Kumulativna kriva raspodele $\mathrm{UM}_{1}$ posle toga naglo poraste za $\mathrm{UM}_{1}=1(96,19 \%)$, a zatim se neznatno povećava $\mathrm{za} \mathrm{UM}_{1}=2$ i 3 , kada dostiže vrednost $100 \%$. Na početnom rastojanju $\mathrm{D}_{0}=2000 \mathrm{~m}$, procenat sukoba u kojima nije bilo uspešnog lansiranja rakete je $21,56 \%$, zato što je vrednost $D_{0}=2000$ $m$ već tolika da počinje da se povećava uticaj sporijih, ali preciznijih raketa na ishod sukoba. Kumulativna kriva raspodele $\mathrm{UM}_{1}$ opet naglo poraste za $\mathrm{UM}_{1}=1$ $(98,08 \%)$, a zatim neznatno raste za $\mathrm{UM}_{1}=2$, kada praktično dostiže $100 \%$. $\mathrm{Za} \mathrm{D}_{0}=2500 \mathrm{~m}$ više nema sukoba u kojima T-1 nije uspeo da lansira raketu koja je doletela do cilja. Skok kumulativne krive raspodele za $\mathrm{UM}_{1}=1$ je i dalje nagao $(93,4 \%)$, a zatim neznatno raste za $\mathrm{UM}_{1}=2$ i 3 do $100 \%$. Najzad, za $\mathrm{D}_{0}=5000 \mathrm{~m}$ nema sukoba u kojima T-1 nije uspeo da uspešno lansira raketu, a za kumulativne raspodele kriva raste sporije i sa zasićenjem $\mathrm{UM}_{1}=1,2$ i 3, kada dostiže $100 \%$.

Na slici 9 prikazane su kumulativne raspodele utroška municije $\mathrm{UM}_{2}$, za 


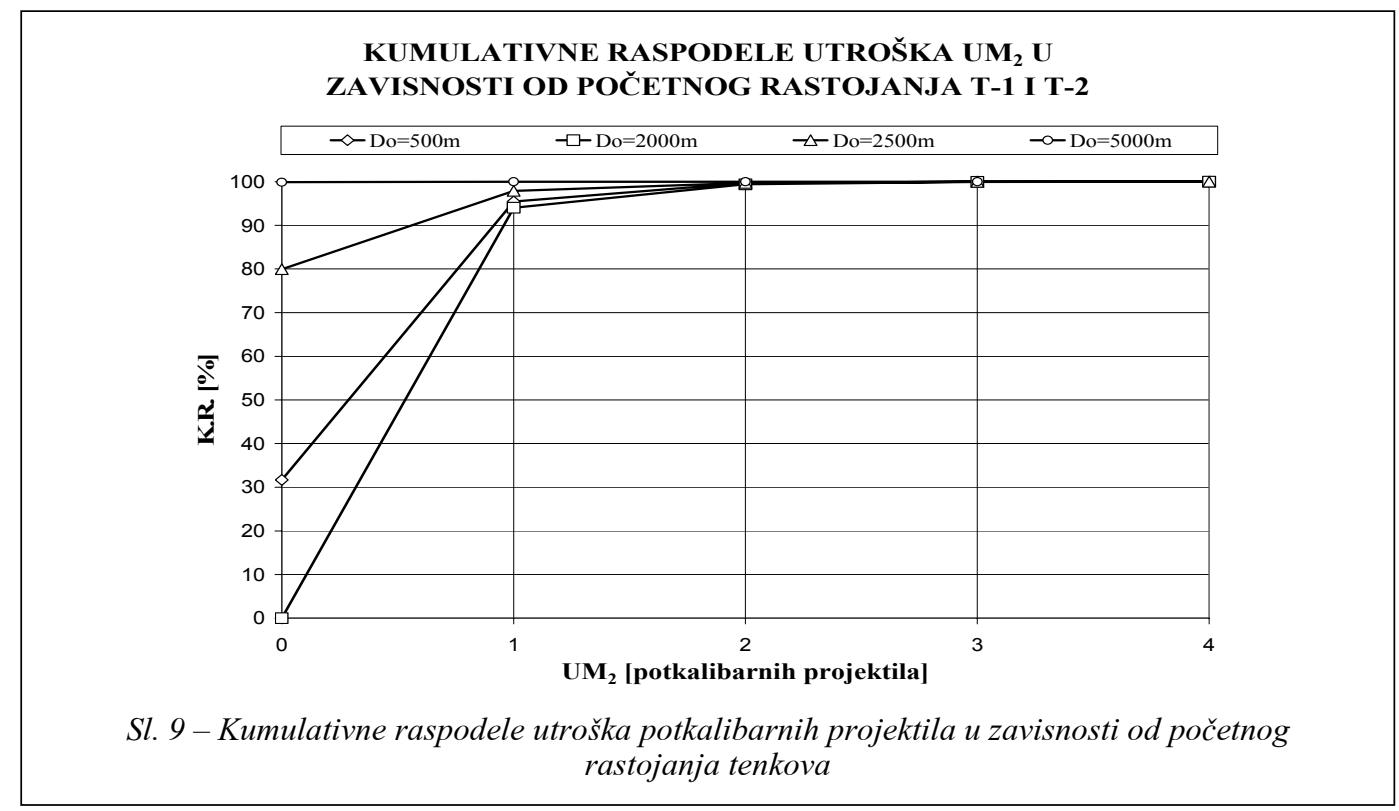

vrednost borbenog kompleta $\mathrm{BK}_{1}=4$ rakete, $\mathrm{u}$ zavisnosti početnog rastojanja tenkova T-1 i T-2 u iznenadnom sukobu. $\mathrm{Na}$ početnom rastojanju $\mathrm{D}_{0}=500 \mathrm{~m} \mathrm{u}$ $31,67 \%$ sukoba tenk T-2 ne uspeva da ispali nijedan potkalibarni projektil na T-1. Kumulativna kriva raspodele $\mathrm{UM}_{2}$ posle toga naglo poraste za $\mathrm{UM}_{2}=1(95,46 \%)$, a zatim se neznatno povećava za $\mathrm{UM}_{2}=2$, kada dostiže vrednost $100 \%$. Skok kumulativne krive raspodele za $\mathrm{UM}_{2}=1$ je i dalje nagao $(94,01 \%)$, a zatim neznatno raste za $\mathrm{UM}_{2}=2$, kada praktično dostiže $100 \%$. Na početnom rastojanju od $\mathrm{D}_{0}=2500 \mathrm{~m}$ tenk $\mathrm{T}-2 \mathrm{u}$ $79,94 \%$ sukoba nije uspeo da ispali nijedan potkalibarni projektil na T-1. Zato sukob počinje izvan efikasnog dometa oruđa OR-2, a zbog preciznosti protivoklopnih vođenih raketa protivnika tenk T-2 ima malo prilike da dođe na rastojanje sa kojeg može da dejstvuje svojim brzim potkalibarnim projektilima. To je naročito uočljivo na početnom rastojanju $\mathrm{D}_{0}=5000 \mathrm{~m}$, kada je kumulativna kriva $\mathrm{UM}_{2}=0$ praktično u svih $100 \%$ sukoba, što znači da na velikim daljinama tenk T1 , naoružan protivoklopnim vođenim raketama, ima apsolutnu premoć.

\section{Zaključak}

Simulacioni model iznenadnog sukoba dva tenka realizovan je u jeziku GPSS World. U analizi rezultata 10 eksperimenata razmatrani su utrošci municije $\mathrm{UM}_{1}$ i $\mathrm{UM}_{2}$ glavnih oruđa tenkova T-1 i T-2, respektivno. Analiza rezultata eksperimenata ukazuje na to da izbor glavnog oruđa znatno utiče na verovatnoću prvog pogotka, odnosno ishod neočekivanog sukoba dva tenka.

Rezultati izvršenih eksperimenata pokazali su da su na minimalnom početnom rastojanju, od $500 \mathrm{~m}$, utrošci municije, kao i verovatnoće prvog pogotka za obe vrste glavnog oruđa, približno iste. Kada se početno rastojanje u sukobu poveća, izdvajaju se tri zone.

U prvoj zoni, do $2000 \mathrm{~m}$, tenk T-2 sa glavnim oruđem, iz kojeg se ispaljuju 
klasični brzi nevođeni potkalibarni projektili, može da ispali više takvih projektila nego tenk T-1 vođenih raketa, pa ima i mnogo više izgleda za prvi pogodak, odnosno pobedu u iznenadnom sukobu.

Od granice dometa topa tenka T-2, na $2000 \mathrm{~m}$, utrošak potkalibarnih projektila se drastično smanjuje, dok raste utrošak protivoklopnih vođenih raketa tenka T-1. Samim tim, sve više rastu i izgledi tenka T-1 na pobedu u iznenadnom sukobu.

Najzad, na većim daljinama, u zoni od 2500 do $5000 \mathrm{~m}$, vođeni raketni projektili imaju apsolutnu prednost.

Ovakve rezultate trebalo bi imati u vidu pri donošenju odluka o tehničkim rešenjima u razvoju novih ili usavršavanju (modernizaciji) postojećih tenkova. Rezultate ovakvih eksperimenata trebalo bi razmatrati uporedo sa nameravanom upotrebom tenkova, jer prednosti otvaranja vatre na velikim daljinama, mogu da se iskoriste samo na zemljištu koje to omogućava (pustinja, velike nizije i sl.). Pravilan izbor glavnog oruđa može doneti velike uštede, kao i mo- gućnosti za poboljšanje ostalih podsistema tenka (komandno-informacioni sistem, pogon, zaštita, i sl.).

Pored toga, ovakvi simulatori mogu se upotrebiti i za simulaciju samih borbenih dejstava, što dolazi do izražaja pri obuci, planiranju, pa i stvaranju novih taktičkih načela borbene upotrebe složenih vojnih sistema.

Literatura:

[1] Janković, R.: Simulacioni model sukoba dve naoružane mobilne platforme, Zbornik radova simpozijuma YU INFO 2001, Kopaonik, 2001.

[2] Janković, R.: Osnovni mehanizmi za simulaciju sukoba dve naoružane mobilne platforme, Zbornik radova simpozijuma YU INFO 2001, Kopaonik, 2002.

[3] Janković, R.: Simulacija uticaja oruđa na sukob dve naoružane mobilne platforme, Zbornik radova XXIX jugoslovenskog simpozijuma o operacionim istraživanjima SYM-OP-IS 2002, Tara, 2002.

[4] Janković, R.: Simulacija uticaja glavnog oruđa na pouzdanost prvog pogotka u neočekivanom sukobu tenkova, Zbornik radova 6. međunarodne konferencije upravljanje kvalitetom i pouzdanonošću DQM-2003, Beograd, 2003.

[5] Janković, R.: Simulacija učinka dejstva glavnog oruđa po protivničkom tenku, Zbornik radova XXX jugoslovenskog simpozijuma o operacionim istraživanjima SYM-OP-IS 2003, Herceg Novi, 2003.

[6] Minuteman Software: GPSS world reference manual, www.minutemansoftware.com 